\title{
Ramón Gómez de la Serna biógrafo de Ramón María del Valle-Inclán. Una aproximación
}

\author{
Jesús Rubio JiméneZ \\ Universidad de Zaragoza
}

Título: Ramón Gómez de la Serna biógrafo de Ramón María del Valle-Inclán. Una aproximación.

Resumen: Ramón Gómez de la Serna dedicó diferentes ensayos a glosar la vida y la obra de Ramón del Valle-Inclán. En este estudio se analiza el proceso de su escritura, sus relaciones internas y cómo contribuyeron a fijar la imagen social del escritor, apoyada, además, en algunas imágenes plásticas de gran impacto.

Palabras clave: Ramón Gómez de la Serna, Ramón del Valle-Inclán, Retrato literario, Biografía.

Fecha de recepción: 3/10/2015.

Fecha de aceptación: 11/10/2015.
Title: Ramón Gómez de la Serna Biographer of Ramón María del Valle-Inclán. An approximation.

Abstract: Ramón Gómez de la Serna wrote several essays to gloss Ramón del Valle-Inclán's life and lifework. The finality of this research is the actualization of his writing process, his internal relationships, the way they contributed to create the social image of the writer, supported by some high impact plastic images.

Key words: Ramón Gómez de la Serna, Ramón del Valle-Inclán, Literary Portrait, Biography.

Date of Receipt: 3/10/2015.

Date of Approval: 11/10/2015.

Ramón Gómez de la Serna cortaba y cosía los trajes de los géneros literarios a la medida de su rotundo corpachón. Por eso son tan holgados, tan elásticos y paradójicamente tan desmedidos. Quiero decir que no cabe esperar en sus retratos y biografías desarrollos convencionales de los mode- 
los habituales, sino una aplicación más de su escritura cocodrilesca ${ }^{1}$. Hacía con su vida literatura, impregnando con su personalidad excesiva cuanto escribía. Agitador incansable de la vida literaria madrileña, desde los años diez trató a numerosos escritores y artistas, dejando testimonios de sus relaciones en sus libros. Era inevitable que el extravagante escritor gallego compareciera en ellos, ya que Valle-Inclán y Gómez de la Serna compartieron escenario durante buena parte de su vida-Madrid-y esto le llevó a acuñar una de las frases que más se han repetido sobre don Ramón:

Era la mejor máscara a pie que cruzaba la calle de Alcalá, y yo recuerdo haberle visto pasar tieso, orgulloso, pero ocultándose de cuando en cuando detrás de las carteleras de los teatros, que eran como burladeros contra las cornadas de aquel público que le llamaba "el poeta melenudo"2.

También la oronda figura de Ramón se iba a convertir en otra de las siluetas inconfundibles de Madrid. Son dos personajes imprescindibles en la galería de tipos de la vida literaria madrileńa del primer tercio del siglo $\mathrm{XX}$, representando generaciones distintas y modos diferentes de vivir la cultura. Valle-Inclán siempre con muchos ecos decimonónicos: era un hidalgo llegado de la periferia gallega que se asentó en la corte y fue descubriendo paso a paso la modernidad, recorriendo un sinuoso camino desde el periodismo provinciano a defender técnicas de escritura de inspiración cinematográfica. Gómez de la Serna, por su parte, era madrileño de nacimiento y desde muy joven tuvo los ojos puestos fuera del país: en París

1 Luis López Molina, "Ramón Gómez de la Serna o el autobiografismo totalizador", en Antonio Lara Pozuelo (coord.), La autobiografía en lengua española en el siglo XX, en Hispánica Helvética, I (1991), pp. 95-105. Véase también Luis López Molina, “El ramonismo: género y subterfugio”, en Mestizaje y disolución de géneros en la literatura hispánica contemporánea, ed. Irene Andrés Suárez, Madrid, Verbum, 1998; e Ignacio Soldevila-Durante, "El gato encerrado (Contribución al estudio de la génesis de los procedimientos creadores de la prosa ramoniana)", Revista de Occidente, 80 (1988), pp. 31-62.

2 Ramón Gómez de la Serna, Don Ramón María del Valle-Inclán, en Obras Completas, XIX. Retratos y biografias, ed. Ioana Zlotescu, Barcelona, Círculo de Lectores I Galaxia Gutenberg, 2002, p. 479. La expresión la había utilizado antes en "Don Ramón del Valle-Inclán”, Retratos contemporáneos, Buenos Aires, 1941, p. 275. 
primero, luego en Lisboa y Estoril o en Buenos Aires con el dinamismo inspirador de las grandes urbes, fugaz e imprevisible. Uno con nostalgias de un mundo que desaparecía - la vieja organización de la vida agraria gallega con sus mayorazgos y sus pequeños propietarios- y el otro, nacido y educado en una ciudad moderna en cambio permanente, sumándose gustoso a los nuevos modos de expresión como la radio o el cine.

Ramón Gómez de la Serna mira con curiosidad a Ramón del ValleInclán, escritor consagrado y ciudadano estrafalario y hasta extravagante 3 . Se mira en el espejo de su literatura y hay que averiguar qué imagen le devuelve. Valle-Inclán no parece haber prestado mucha atención a Gómez de la Serna; cuesta encontrar y aducir algún testimonio del escritor gallego sobre el madrileńo. Ni positivo ni negativo. Por el contrario, abundan los del primero, formando un corpus notable con una estructuración creciente nacida de la continua decantación de los materiales hasta constituir su versión última una de las biografías de don Ramón más leídas y citadas durante mucho tiempo: Don Ramón María del Valle-Inclán, publicada en Buenos Aires en 1944, es decir, relativamente cercana a la muerte de Valle-Inclán y escrita cuando Ramón aceptaba encargos biográficos como un medio de supervivencia, aunque sin renunciar a su personal escritura ${ }^{4}$.

Las circunstancias resultan determinantes en sus escritos sobre ValleInclán, que es quien aquí importa: operaba a base de recuerdos de su trato con don Ramón, refrescados con la contemplación de retratos del biografiado y releyendo escritos suyos o sobre él glosando su singular personalidad. Fue sumando todo ello en sucesivas aproximaciones al perso-

3 Sobre los valores positivos de la extravagancia, véase Jesús Rubio Jiménez, "Elogio de la extravagancia", referido al escritor e incluido en Valle-Inclán, caricaturista moderno. Nueva lectura de "Luces de bohemia", Madrid, Fundamentos, 2006, pp. 309-328.

4 De 1943 es Don Diego Velázquez (Buenos Aires, Editorial Poseidón, con 135 páginas, pero con 70 ilustraciones en blanco y negro y cuatro en color) y durante los años siguientes continuó enjaretando biografías de Lope, Quevedo, El Greco, Goya o Gutiérrez Solana. También retratos, que recopiló en Retratos contemporáneos en 1941. Aún añadiría un nuevo volumen de Nuevos retratos contemporáneos en 1946, reuniendo escritos nuevos con otros rescatados de su dispersa obra anterior, donde siempre el retrato y la biografía estuvieron muy presentes. Retratos y biografías ocupan varios volúmenes de sus Obras completas, aunque otros esperan todavía la mano de nieve que los rescate de las páginas de revistas y periódicos, o de archivos sonoros de la radio y sus correspondientes guiones escritos. 
naje, que culminaron en la biografía citada. El camino recorrido va de la impresión y la anécdota, al ensayo amplio integrador de materiales diversos; de la silueta al cuadro completo; del retrato biográfico a la biografía. Estos escritos forman una nube en expansión, que se tornasola según los momentos y donde hallamos desde unas primeras impresiones negativas -inevitables en un joven literato iconoclasta- a genuinos retratos, una breve biografía de urgencia a poco de fallecido el escritor, nuevos artículos con anécdotas "inéditas" o numerosas alusiones en escritos más amplios de Ramón sobre la vida literaria madrileñas.

En general, en toda la obra de Gómez de la Serna hay un aprovechamiento continuo de materiales, algo inevitable en el mundo moderno del periodismo y Ramón vivió en gran parte de su actividad en los periódicos y en otros medios, incluidos los encargos editoriales. Los escritores de periódicos son bóvidos que mastican y rumian una y otra vez las mismas hierbas hasta sacarles todo el jugo; en ocasiones, al exprimirlas por última vez, sale un último jugo decantado y esencial. Acaso no sea excesivo ver así su biografía de don Ramón publicada en 1944: después de haber rellenado su oronda panza de hierba de don Ramón -recuerdos, lecturas, imágenes-, Ramón la rumió una vez más con cierta pausa para sacarle

5 Los principales: alusiones despectivas en Morbideces, en la "Depuración preliminar" de Teatro en soledad y en "Palabras en la rueca"; después con carácter autónomo: "Algunas versiones de cómo perdió el brazo don Ramón María del Valle-Inclán”, Muestrario, Madrid, 1918, pp. 273-287; "Comment Don Ramón, Marquis del Valle-Inclán, perdit un bras”, Hispania (Paris), I (1918) pp. 329-331; y (1919), pp. 64-70; "La personalidad fantasmagórica de Valle-Inclán”, La Pluma, 32 (1923), pp. 71-81, recopilado en El alba y otras cosas, Madrid, 1923, pp. 104-115; "Ramón del Valle-Inclán”, Azorín, Madrid, La Nave, 1930, pp. 105-115, después en Buenos Aires, Losada, 1942, 1948, 1957, pp. 105-115; "El escritor en la enfermería”, Nuevo Mundo, 18-7-1924; "Tribuna libre: greguerías", Luz, 17-3-1934. "Vida y milagros de don Ramón del Valle-Inclán”, Revista de las Indias, 28 (1941), pp. 191-208; “D. Ramón del Valle-Inclán”, Retratos contemporáneos, Buenos Aires, Sudamericana, 1941, pp. 171-240; "Anecdotario inédito de Valle-Inclán”, La Nación (Buenos Aires), 26-4-1942; "Misterio de Valle-Inclán. Nuevas palabras sobre su estética y sobre su barba", La Nación, 25-4-1943; Don Ramón María del Valle-Inclán, Buenos Aires, Espasa Calpe, 1944; y "Primera presencia madrileña de D. Ramón María del ValleInclán”, Villa de Madrid, 19 (1967), pp. 13-18. Los citados a lo largo del texto, lo serán sobre todo a partir de su Obras completas, publicadas en Barcelona, Círculo de Lectores/Galaxia Gutenberg. 
el último jugo. En sus escritos valleinclanianos dejó señales del proceso seguido, que ayudan a entenderlo, como se verá, tras unas indicaciones generales de su poética del retrato y la biografía.

\section{Poética del retrato y de la biografía en Ramón Gómez de la Serna}

Quienes han analizado los muchos retratos y las varias biografías que Ramón escribió han descrito su poética sobre estas modalidades de escritu$\mathrm{ra}^{6}$. Ramón con su particular vitalismo en sus retratos y biografías tendía puentes entre su vida y la de aquellos a quienes retrataba o biografiaba, sin olvidar, además, referirse a los lectores, a quienes incorpora también a su discurso. Si todos sus escritos se hallan penetrados de autobiografismo desde sus años mozos, aún se intensifica más esta proyección en sus retratos y biografías, y cuando expuso El concepto de la nueva literatura en

6 Con carácter general: Andrés Soria Olmedo, "Notas sobre la biografía en España (Años veinte-treinta)", Serta Philologica: Fernando Lázaro Carreter, III, Madrid, 1983, pp. 531-540; Enrique Serrano Asenjo, Vidas oblicuas: Aspectos teóricos de la nueva biografía en España (1928-1936), Zaragoza, Prensas Universitarias, 2002; Manuel Pulido Mendoza, Plutarco de moda. La biografia moderna en España (19001950), Mérida, Editora Regional de Extremadura, 2009; Jesús Rubio Jiménez, "Un marco para el retrato literario modernista. Ensayo de aproximación”, en Literatura hispánica y prensa periódica (1875-1931). Actas del Congreso Internacional, Lugo 2528 de noviembre de 2008, Santiago de Compostela, Universidade de Santiago de Compostela, 2009, pp. 323-356; Francisco Miguel Soguero García, "Los narradores de vanguardia como renovadores del género biográfico: aproximación a la biografía vanguardista”, en Francis Lough (ed.), Hacia la novela nueva. Essays on the Spanish Avant-Garde Novel, Oxford, Peter Lang, pp. 199-227. Referidas a Ramón Gómez de la Serna: Elpidio Laguna Díaz, Las biografías y retratos de Ramón Gómez de la Serna, Puerto Rico, Editorial Club de la Prensa, 1974; María Antonia Salgado, "La visión humorística en los Retratos de Ramón Gómez de la Serna", Papeles de son Armadans, LC (1969), pp. 15-25; Enrique Serrano Asenjo, "Las biografías de escritores de Ramón Gómez de la Serna y su poética encubierta: los contemporáneos", Revista Canadiense de Estudios Hispánicos, XXX (2005), pp. 171-187; Susana Arnas, El arte del retrato y de la biografía en Ramón Gómez de la Serna, Zaragoza, Universidad de Zaragoza, 2011, tesis doctoral. Y necesariamente se han topado con sus retratos y biografías quienes se han ocupado sobre la autobiografía ramoniana, como Jacqueline Heuer, La escritura (auto)biográfica en Ramón Gómez de la Serna, Gèneve, Editions Slatkine, 2004. 
1909 ya insistía en que "toda obra ha de ser principalmente biográfica y si no lo es, resulta cosa teratológica. Las que están hechas en otro concepto, resultan intempestivas, voraces con la voracidad de lo que os descarna espiritualmente para corporizar cosas extrañas"7.

El retrato o la biografía eran para él procedimientos de exploración y apropiación de los personajes tratados. Comenzó en las páginas de su revista Prometeo el cultivo del retrato literario en 1908 y desde 1916 el de la biografía, dedicando su atención a escritores de los que se consideraban en la tradición modernista raros. Años después escribía:

Cuando la biografía no se había puesto de moda -allá por el 1916yo ya encabezaba con largas y cordiales biografías a mi manera -bajo el signo del vitalismo muerto- las obras de Ruskin, de Baudelaire, de Villiers, de Nerval, de Oscar Wilde, etc.

Pasado el tiempo, coleccioné en un tomo, titulado Efigies, parte de estas biografías y seguí escribiendo otras nuevas, sobre Quevedo, Lope, Fígaro, Goya, El Greco, mi tía Carolina Coronado, Gutiérrez Solana, Azorín, Silverio Lanza, y otra vez tengo que apelar al etcétera.

Dos grandes tomos dedicados al Café de Pombo aglomeran más biografía desde la de Julio Antonio a la del último poeta llegado a la sagrada Cripta.

En el libro Ismos amontono todas las figuras del arte innovador desde Apollinaire a Picasso, pasando por Cocteau.

En mis conferencias he afrontado figuras como las de Edgar Poe, de cuya vida tengo una idea detallada, dramática, ejemplar, considerándole el genio de América, además del más desolado de los poetas ${ }^{8}$.

Y fue por aquellos años cuando comenzaron a hacerle encargos biográficos. Cumplirá con su cometido aprovechando para autobiografiarse, antes de emprender su gran proyecto autobiográfico: Automoribundia, verdadero testamento de un escritor desencantado del oficio tras decenios de

7 Ramón Gómez de la Serna, "El concepto de la nueva literatura", en Una teoría personal del arte, ed. de Ana Martínez Collado, Madrid, Tecnos, p. 62. Ioana Zlotescu, "El retrato, espejo del autorretrato y refugio de la autobiografía. De Prometeo a Pombo", Turia, 41 (1997), pp. 120-126.

8 Ramón Gómez de la Serna, Obras completas, XVII. Retratos completos, p. 31. 
lucha y de escribir abundantemente sobre el desencanto de muchos otros. Mantuvo siempre un interés por los raros contemporáneos y extendió sus averiguaciones a grandes personajes del pasado, mostrando preferencia por personajes singulares y por coetáneos a los que trató y conoció:

He preferido siempre en las biografías, dejándome guiar por esa libertad de intención, a los seres singulares, a los originales, a los que están nimbados por el desinterés, por la bohemia, por la pureza imposible, por la conducta llena de fidelidad, por la simpatía que emanan al haberse atrevido a ser los seres pintorescos y transeúntes de una época, dando romanticismo, novelería, galantería y gracia a sus calles?

Y en otro momento decía:

El hombre que se destaca entre los miles de millones de hombres que compartieron su tiempo merece un trato lento y emocionado que revele lo que tuvo de pintoresco, sin dejar de revelar lo que tuvo de profundo al intentar decir algo nuevo sobre el enigma humano, logrando escribir su nombre en la oscura pizarra del anonimato ${ }^{10}$.

Desde pronto rechazó a quienes consideraba desfasados y anclados en el pasado. A su práctica de la escritura biográfica añadió una reflexión sobre ella, mostrando cómo para él esta indagación en otras vidas lo era en la suya y por eso decía:

meto historia propia, ayes propios, matices y vericuetos propios en esas biografías; pero siempre es "de otro" de quien trato y además, a conciencia, porque mi empeño es no mentir; es que si algún día me encuentro con el biografiado -alguna vez todos nos hemos de encontrar- no me reclame la verdad que no dije y me desafíe por las mentiras que llegué a decir ${ }^{11}$.

Cuando se trataba de no contemporáneos sostenía que el público quiere

9 Ibidem, p. 32.

10 Ibidem, p. 382.

11 Ramón Gómez de la Serna, Obras completas, XIV. Retratos autobiográficos, II. Cartas a mi mismo, Barcelona, Círculo de Lectores-Galaxia Gutenberg, 2002, p. 674. 
“esa mezcla de las almas antiguas con las almas contemporáneas", que es otro modo de decir lo mismo ${ }^{12}$. Así se hacían, según él, más contemporáneos los hombres del pasado. Es decir, no renunciaba nunca al sello personal, a introducirse en lo relatado dando lugar a escritos híbridos, reveladores tanto del retratado o biografíado como de su retratista o biógrafo. Sabía que toda representación conlleva una interpretación y que era necesario combinar bien los ingredientes anecdóticos con otros para que el retratado o biografiado resultara vivo, cercano. Y en la "Advertencia preliminar" a su biografía de Quevedo daba algunas pistas más sobre su manera de proceder:

Mis biografías son unas biografías particulares.

Me detengo en lo que creo esencial y paso de largo lo que es solo arrendajo y embrollo, que enturbia la pujanza del retratado.

Le dejo a él solo o le acompaño según las circunstancias.

[...] En las biografías vale el soplo, el empellón, el cerrar los ojos y abrirlos de súbito, los momentos destacados, las ráfagas.

[...] Desmenuzar la biografía, mamotrearla y prontuariarla con noticias inútiles o premiosas, es no dar su conjunto de mascarón de proa y fachada que deben representar el Madrid eterno.

Con este criterio plástico, blasonal, caratulesco de fachada madrileña está escrita esta biografía ${ }^{13}$.

2. Retratos y biografías de Ramón del Valle-InClán escritos por Ramón Gómez de la Serna

Sus escritos biográficos sobre Valle-Inclán tienen la particularidad de referirse a uno de los escritores que sintió más cercanos. Lo miró y analizó desde sus años mozos, al principio con recelo, después con creciente admiración porque personalizó en él y en Azorín la figura del escritor español que mantiene la dignidad de su oficio contra viento y marea. En este sentido, sus biografías sobre estos escritores son un prólogo muy

12 Ramón Gómez de la Serna «Prólogo» a Obras completas, XIX. Biografías de escritores, Barcelona, Círculo de Lectores-Galaxia Gutenberg, 2002, p. 809.

13 Ramón Gómez de la Serna, "Advertencia preliminar" a Quevedo, en Obras completas, XIX. Biografias de escritores, pp. 969-970. 
revelador para su desencantada Automoribundia. Compitió con ellos en dedicación entera y hasta absoluta a la escritura. Al escribir sus biografías ponía cierto orden en su proceso de apropiación del modelo de escritor que eran para él. Se miraba en sus vidas y en los espejos de tinta de sus obras, buscando claridad en su negrura. Ayuda la escritura sobre la vida de otro escritor a indagar y escribir sobre la propia vida:

Un escritor visto en su espontánea y alegre inspiración nos ensancha la vida, y viniendo del pasado nos lleva al porvenir; pero ese mismo escritor, visto por el "notero", nos lleva al pasado y nos obliga a una muerte desecada, vieja muerte en otro tiempo ${ }^{14}$.

El camino recorrido va de la impresión al intento de aprehender lo esencial de la personalidad del retratado. De lo anecdótico a lo sustancial. No es secundario lo anecdótico sino que tiene el valor de primera impresión, de síntoma, muestra la piel del personaje, su boceto, su silueta. $\mathrm{O}$ es emanación de estos cuando el personaje tiene una personalidad pública, que lo dota de una imagen dentro del cuerpo social. Después viene su desarrollo y del trazo rápido y fugaz se pasa al análisis sintético que exige la semblanza o al análisis de la personalidad, a la interpretación del biografiado que siempre necesita una biografía que se precie de tal, aunque sea apoyándose más en la videncia -como hará Ramón- que en los datos.

Todo este proceso se ve muy bien en la biografía que escribió sobre $A z o$ rín; es una galería de escritores de su generación con una valoración en ocasiones despiadada de algunos de ellos ${ }^{15}$. Salva siempre al escritor alicantino, porque para él era el prototipo del escritor, el maestro dedicado absolutamente como un verdadero monje a su oficio y le producía admiración por ello $^{16}$. Lo mismo le ocurrió con Valle-Inclán, a quien situará en lugar pree-

14 Ibidem, p. 969.

15 Ramón Gómez de la Serna, Azorín, en Obras completas, XIX. Biografias de escritores. 16 Así lo había presentado ya Clarín en un "Palique" (Madrid Cómico, 9-2-1899) cuando publicó Los hidalgos: "Otros ahorcan los libros y se meten a predicar libertariamente. / Martínez Ruiz, de veras, se fue del púlpito a la biblioteca. Dejémosle en paz. / Que estudie, que estudie. / Respetemos el culto a esa especie de oración perpetua. / En Espańa la vida del verdadero estudiante, es vida monástica, en la rigorosa acepción de la palabra...”. La identificación entre dedicación a la literatura y la vida monacal, retirada y austera, serán habituales en las referencias a estos 
minente en esa galería de escritores que rodea a Azorín en su biografía ${ }^{17}$. De joven, no obstante, había escrito comentarios despectivos. En Morbideces:

Los otros viejos, los especuladores, que quieren imponerse hablando de su mucho trabajo y que señalan sus estanterías repletas como merecimiento respetable no saben que una de nuestras clarividencias reasume y sobrepasa toda su obra de trabajo.

Esos prohombrillos, se llaman Azorín, Baroja, Valle-Inclán, Trigo, Martínez Sierra, Rueda, etc., etc.

[...] Azorín es una edición en octavo menor de la obra en folio de Anatole France, en cuya traducción libre ha incluido algo de su espíritu y del espíritu castellano; con un arte apelmazado de notario, con una meticulosidad consistente, árida e impersonal, hace el inventario del paisaje, de las cosas y de los gestos.

[...] Valle-Inclán, que ha abusado del corazón -ese desmayo de sensualidad intelectualizada-, quiere reivindicarse a última hora con sus deliquios d'anuncianos de crueldad y de fiereza, que si en el breńal son emocionantes y pintorescos, en el trasunto son monótonos y $\operatorname{contrahechos}^{18}$.

Les achacaba indecisión y timideces en su escritura, discursos ya envejecidos. En la "Depuración preliminar" de su Teatro en soledad afirmaba que de la generación anterior solo quedaban unas páginas de Azorín, pero que luego se llenó de miedos. Quizás se refería a sus escritos anarquistas no muy distintos a algunos suyos en ese momento. Ramón no dejaba títere con cabeza y Valle-Inclán era visto aún como "ese hombre opaco de lirismos tópicos, de experiencia y larga retención, hijo de una ira artística

escritores. Valle-Inclán alimentó está figuración desde muy pronto, como analicé en "Juego de espejos: retratos y caricaturas de Valle-Inclán”, en Valle-Inclán caricaturista moderno, pp. 190-200 y 223-228. Y el propio Ramón Gómez de la Serna adquirirá con el tiempo esa misma cualidad en algunas semblanzas. Véase Antonio Tovar, "Ramón asceta", Ensayos y peregrinaciones, Madrid, Guadarrama, 1960, pp. 287-299.

17 Ramón Gómez de la Serna, "Ramón del Valle-Inclán", en Obras completas, XIX. Biografias de escritores, pp. 114-120.

18 Ramón Gómez de la Serna, Morbideces, en Obras completas, I. Escritos de juventud (1905-1913), Barcelona, Círculo de Lectores-Galaxia Gutenberg, 1996, pp. 493494. 
iracunda en su suavidad y su cautela, enormemente premeditada..."19. Tampoco Baroja o Unamuno salían mejor parados, acusado este de "imitador y vulgarizador plomizo de la locuras inimitables..." ${ }^{20}$. José-Carlos Mainer llega a decir que en ese momento Valle-Inclán era su "verdadera bestia negra" 21 . Con su manera de escribir rompedora y cocodrilesca de entonces no podía admitir el discurso de estos escritores consagrados de mayor edad. Y no entendía que justamente la exploración de la palabra en sus posibilidades era también la aspiración simbolista de escritores como Valle-Inclán. De Valle-Inclán decía en "Palabras en la rueca":

La palabra, ¿qué saben de la palabra los escritores? Todos, hasta esos estilistas como ese hombre incierto que no tiene más que dibujo, ese ValleInclán, no saben ser desprendidos y escaparse a sus amigos mediocres y a su propia amistad pesada y rancia, y hablan en medio de todo un lenguaje comercial y vano, lleno de todos los tópicos de la palabra y de toda su flojedad, acusándose por sintaxis aún; una palabra conformada por todo el alrededor y todo el ceremonial, más que por ella misma, dentro de la farsa de las palabras y de su rendición, sin una sola trimegista, sin que unas en otras disocien con fuerza la tendencia a los latiguillos y a las similitudes con toda la tradición ayuna y tuberculosa; en ellos la palabra no tiene nada esforzado, no tiene todas las reminiscencias que debe tener y todas las introspecciones y todas las iniciaciones aventuradas, expuestas a no ser más que precursoras sin éxito y sin admiración... ${ }^{22}$

Pero con el correr de los años cambió y sintió verdadera pasión por escribir la biografía de Azorín -lo hizo en 1930- o la de Valle-Inclán, que culminaría en 1944. La construcción de la imagen positiva de Valle-Inclán por parte de Gómez de la Serna se realizó -como queda dicho- paralela a la construcción de la imagen del escritor como héroe en un país ajeno a su vida intelectual.

19 Ramón Gómez de la Serna, Obras completas, II. Prometeo, II. Teatro de juventud (1909-1912), Barcelona, Círculo de Lectores / Galaxia Gutenberg, 1996.

20 Ibidem, 155.

21 José-Carlos Mainer, "Prólogo”, en Ramón Gómez de la Serna, Morbideces, en Obras completas, I. Escritos de juventud (1905-1913), p. 116. Aduce como pruebas, además de estos textos, una nota anónima de Prometeo $(37,1912)$ acusándole de haber plagiado en La marquesa Rosalinda la obra de Jean Louis Vaudoyner, La noche persa.

22 Ramón Gómez de la Serna, "Palabras en la rueca", Obras completas, I. Escritos de juventud (1905-1913), pp. 880-881. 
Se fue dando cuenta de que había escritores anteriores que podían servirle de modelos literarios y vitales: Azorín, Valle-Inclán. Por eso en los años veinte los frecuenta y escribe sobre ellos con un tono muy diferente, y aunque tenía su propia tertulia en el Café de Pombo, no por eso dejaba de pasar de vez en cuando por las de Valle-Inclán, coincidiendo además en banquetes y por las calles de Madrid. Hasta lo recordaba participando en el banquete pombiano dedicado a Don Nadie con Zuloaga y Ricardo Baroja ${ }^{23}$ [Figs. 1 y 2].

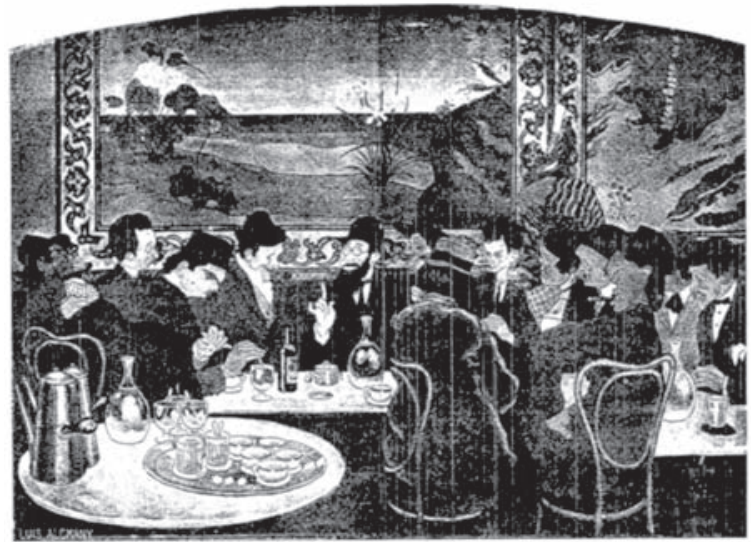

Luis Alemany, "La tertulia de Levante”, Pharos, núm. 4, abril de 1912

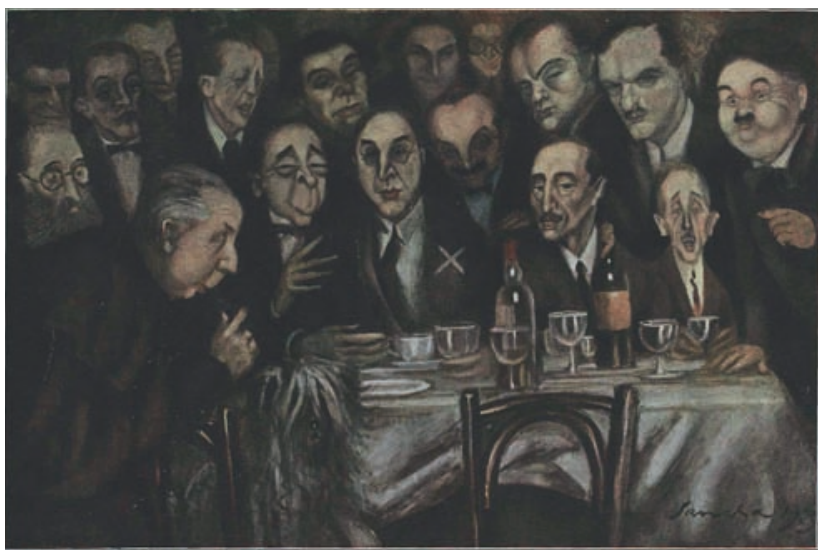

Francisco Sancha, "Supuesto banquete al escultor Miranda”, La Esfera, núm. 696, 7/IV/1927.

23 Ramón Gómez de la Serna, Don Ramón Maria del Valle-Inclán, en Obras completas, XIX. Retratos y biografias, IV, p. 575. Lo describió en su libro sobre Pombo. 
En el caso de don Ramón fue perfilando el personaje y algunas anécdotas alcanzaron una notoriedad evidente. Por ejemplo, las relacionadas con la pérdida del brazo sobre las que escribió en 1918: "Algunas versiones de cómo perdió el brazo don Ramón María del Valle-Inclán”, en Muestrario ${ }^{24}$. Buena parte de estas anécdotas pasarán ligeramente retocadas a escritos posteriores y ocupan varias páginas en la biografía de 1944, como puede verse en este sucinto careo:

Ramón María del Valle-Inclán ${ }^{25}$

El hambre del hidalgo (pp. 501-502)

El brazo relicario (502)

La aventura con el león (502)

El ladrón de brazos (502)

La nueva mujer de Putifar (503)

El bandido Quirico (503)

\section{Muestrario $^{26}$}

El hambre del hidalgo (pp. 661-662)

En Versiones a granel (662)

El león (661)

En Versiones a granel (663)

La nueva mujer de Putifar (654)

El bandido Quirico (656)

Otras veces las anécdotas son solo aludidas de pasada cuando ya ha pasado un tiempo desde su primera mención:

El brazo perdido picado

por un halcón hambriento (504)

El halcón (655)

Exvoto en una ermita (504)

Exvoto (660-661)

Envío a Barbey d'Aurevilly (504)

Barbey d'Aurevilly (656-657)

Semisuicidio heroico al ver que el rey

don Carlos solo condecora mutilados (504)

La gran cruz (656-657)

24 Ramón Gómez de la Serna, «Algunas versiones de cómo perdió el brazo don Ramón María del Valle-Inclán», en Muestrario, Madrid, 1918, pp. 273-287. El aprovechamiento de este anecdotario en una colaboración francesa: "Comment don Ramón, Marquis del Valle-Inclán, perdit un bras”, Hispania, I (1918), pp. 329-331; y (1919), pp. 64-70.

25 Las páginas corresponden a Ramón Gómez de la Serna, Ramón María del ValleInclán, en Obras completas, XIX. Retratos y biografias.

26 Las páginas corresponden a Muestrario, en Obras completas, IV. Ramonismo II, Greguerías. Muestrario (1817-1919), Barcelona, Círculo de Lectores / Galaxia Gutenberg, 1997. 
Y también se había producido un aprovechamiento narrativo del triste suceso, incorporándolo en Sonata de invierno transformado. Ramón lo recuerda y cita en Muestrario ${ }^{27}$. Lo curioso es que en Muestrario afirmaba lo siguiente:

Entre mis versiones de esa pérdida, las hay inventadas, hay otras que he oído contar; como muestra del ingenio de don Ramón está la que él ha escrito en su Sonata de invierno y está la verídica ${ }^{28}$.

En la biografía de 1944 dirá:

Un adelfo de anécdotas iba a surgir de aquel brazo desaparecido. [...] Un día, pasados los años, yo me atrevía a lanzar unas inventadas versiones de cómo perdió el brazo don Ramón. [...] Don Ramón fue condescendiente con mis invenciones, exclusivamente mías, aunque después los mentirosos que escriben por referencias hayan hablado de un editor al que se le ocurrió una cosa por el estilo.

Entre esas versiones de un día de alegre imaginación de mi pasado voy a elegir unas cuantas... ${ }^{29}$

Pasado el tiempo decide por tanto apropiárselas todas, convirtiéndolas en microrrelatos -como se diría ahora-, con su punto fantástico o macabro. El retrato y aun la biografía, entreverados de anécdotas, quedan así afirmados y ya no abandonará nunca el procedimiento. Y además, con esa mezcla de testimonio e invención fantástica que tan bien cuadraban al personaje.

El primer escrito importante, sin embargo, de Ramón sobre don Ramón fue "La personalidad fantasmagórica de Valle-Inclán" [Fig. 3], publicado en La Pluma, en enero de 1923, en el número monográfico que le dedicó al escritor gallego la revista de Manuel Azaña ${ }^{30}$. Un homenaje memorable por-

27 Ramón Gómez de la Serna, Obras completas, IV. Ramonismo II, Greguerías. Muestrario (1817-1919), pp. 657-658.

28 Ibidem, p. 651.

29 Ibidem, pp. 500-501.

30 Ramón Gómez de al Serna, "La personalidad fantasmagórica de Valle-Inclán”, La Pluma, 32 (1923). Se cita aquí, sin embargo, por la versión recopilada en El alba 
que ofreció algunos de los mejores retratos literarios y plásticos del escritor. Don Ramón dio a la luz en aquella revista Farsa y licencia de la reina castiza, Los cuernos de don Friolera y Cara de Plata. Fue una plataforma indispensable para entender su vuelta al mundo literario madrileño después de haber pasado varios ańos en Galicia dedicado a la agricultura, hasta que se arruinó ${ }^{31}$.

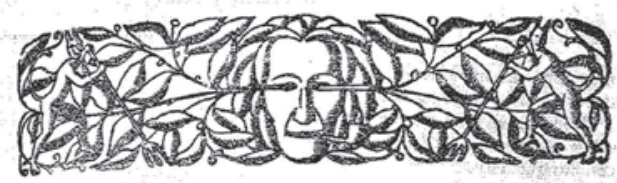

LA PERSONALIDAD FANTASMAGÓRICA DE DON RAMÓN

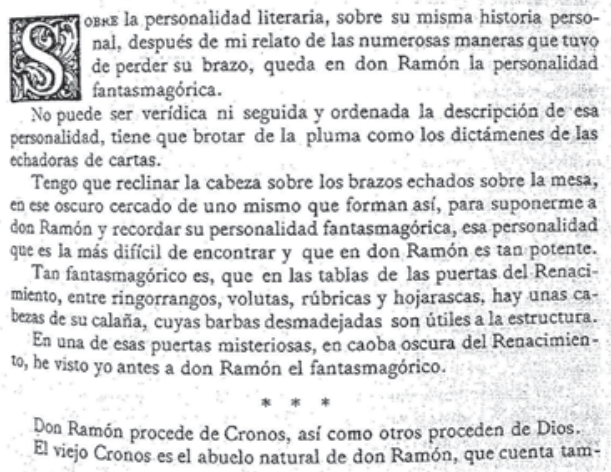

Fig. 3. Ramón Gómez de la Serna, "La personalidad fantasmagórica de Don Ramón”, La Pluma, núm. 32, enero de 1923.

Entre los homenajes plásticos, destaca el del pintor cordobés, nacido en Priego, José Moya del Pino [Figs. 4 y 5], autor de varios retratos inol-

y otras cosas (Madrid, 1923), incluida en Obras completas, V. Ramonismo, III. Libro nuevo. Disparates. Variaciones. El alba (1920-1923), Barcelona, Círculo de Lectores I Galaxia Gutenberg, 1999, pp. 856-865.

31 Jean Marie y Eliane Lavaud, "Valle-Inclán y La Pluma ", La Pluma, 2a época, 2 (septiembre-octubre de 1980), pp. 35-45. 
vidables del escritor. Formaba parte de la tertulia de Valle-Inclán desde que llegó a comienzos de los años diez a Madrid. Compartía tertulia con otros como Julio Romero de Torres, también buen amigo del escritor gallego $^{32}$. Con otros artistas amigos realizaron una bellísima edición de Voces de gesta ${ }^{33}$. Reprodujeron también en La Pluma un retrato de Juan de Echevarría, otro de los pocos amigos con quienes don Ramón compartió su intimidad en sus largos paseos por Madrid ${ }^{34}$.

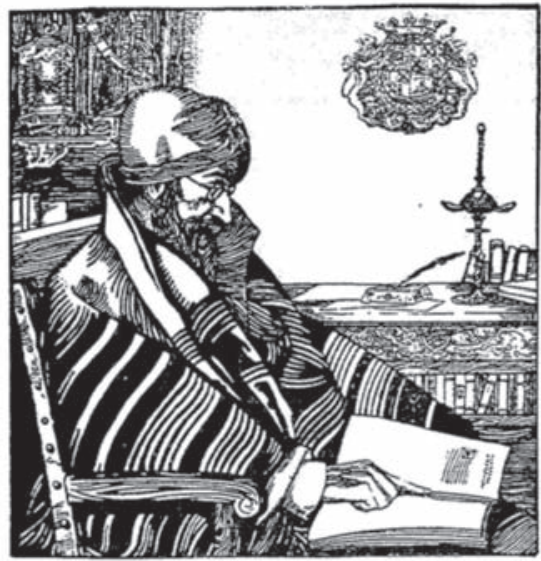

Moya del Pino, "Valle-Inclán”, La lámpara maravillosa, Madrid, SGEL, 1916.

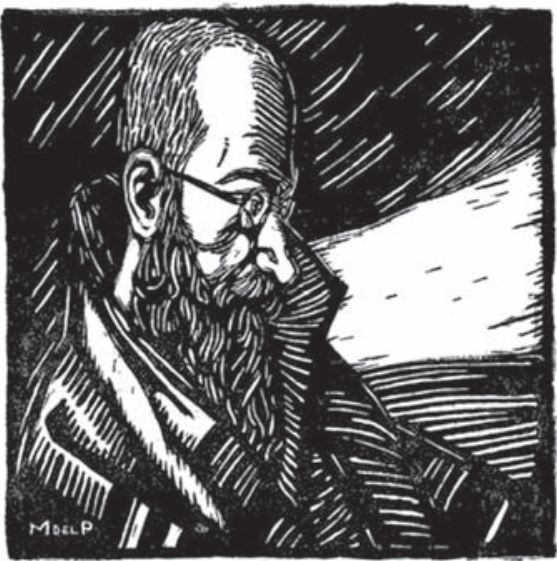

Moya del Pino, "Valle-Inclán”, La Pluma, núm. 32, enero de 1923.

Todo el número monográfico de La Pluma ofrece una galería de retratos literarios, complementarios de los anteriores, que podríamos analizar aquí como un modelo perfecto de homenaje. Me limito, sin embargo, a

32 Margarita Santos Zas, "Valle-Inclán, de puño y letra: notas a una exposición de Romero de Torres", ALEC, 23.1 (1998), pp. 405-450.

33 He explicado sus relaciones en distintos lugares: Jesús Rubio Jiménez, "Valle-Inclán retratado por José Moya del Pino: la melancolía moderna”, Moralia 8 (2008), pp. 24-36; "Valle-Inclán y Moya del Pino: buscando el fiel de la balanza (I)", ALEC / Anuario Valle-Inclán, 37.3 (2012), pp. 57/845-98/886; y "Valle-Inclán y Moya del Pino: buscando el fiel de la balanza (y II)", ALEC / Anuario Valle-Inclán, 39.3 (2014), pp. 49/591-77/619.

34 Dru Dougherty, "Valle-Inclán y la pintura: la exposición de Juan de Echevarría (Madrid y Bilbao, 1923)", Boletín de la Fundación Federico García Lorca, 17 (1995), pp. 65-87. 
“La personalidad fantasmagórica de Valle-Inclán”, de Gómez de la Serna, retrato literario que va acompañado de uno de los más sorprendentes retratos plásticos que nunca se han hecho de Valle-Inclán, firmado por Ángel Vivanco: "Valle-Inclán, fantasmagoría de Vivanco". En él, don Ramón, con la imagen esquelética de un faquir, aparece fumando una pipa de kiff a lomos de una llama [Fig. 6].

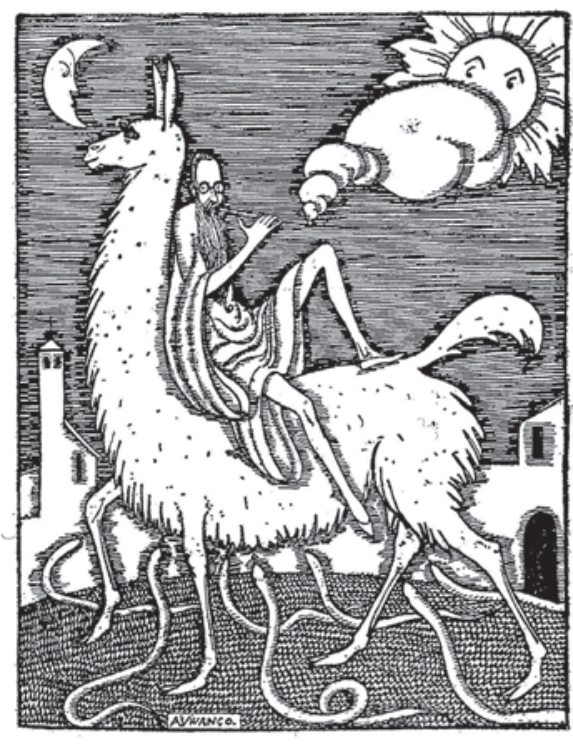

Valle-Inclán, fantasmagoria de Vlvanco.

Ángel Vivanco, "Valle-Inclán, fantasmagoría de Vivanco", La Pluma, núm. 32, enero de 1923.

Resultan enigmáticos y hasta desconcertantes a primera vista algunos elementos de la composición: va montado en una llama y hay serpientes a sus pies. Repasando su obra conocida, lo más cercano que recuerdo de Vivanco son algunas de las representaciones de Moctezuma en la biografía de Hernán Cortés de la Pardo Bazán ${ }^{35}$. Ramón era consciente de

35 Se sabe poco de este extraordinario ilustrador -diseñador de La Pluma-, que colaboró bastante con Valle-Inclán en los años veinte, ornamentando varios volúmenes de Opera Omnia: en 1920, Los cruzados de la causa (Opera Omnia XXII), Flor de santidad (Opera Omnia II, con Moya del Pino); en 1922, Romance de lobos (Opera 
estar escribiendo un ensayo diferente al que he comentado, construido mediante un ensartado de anécdotas:

Sobre la personalidad literaria, sobre su misma historia personal, después de mi relato de las numerosas maneras que tuvo de perder su brazo, trazado en mi libro Muestrario, queda en don Ramón la personalidad fantasmagórica.

No puede ser verídica y seguida ni ordenada la descripción de esa personalidad, tiene que brotar de la pluma como los dictámenes de las echadoras de $\operatorname{cartas}^{36}$.

Gómez de la Serna ensayó una definición de la "personalidad fantasmagórica” de Valle-Inclán, una de las modalidades de personalidad que juzgaba escasas, por su vida azarosa y estrafalaria, que sus viajes a América y su vuelta mísera reforzaban haciendo de él un tipo excéntrico y desafiante, pero sobre todo "misterioso" de acuerdo con la acepción del término en el diccionario de la Academia.

Ramón adelantaba su manera de escribir el retrato: "No puede ser verídica ni seguida y ordenada la descripción de esa personalidad, tiene que brotar de la pluma como los dictámenes de las echadoras de cartas”. Es decir, recurre a su procedimiento de escritura biográfica como un ejercicio de videncia del biografiado. Su texto es una sucesión de flashes, definiendo por aproximación y adivinación al retratado teniendo delante

Omnia XV), Sonata de primavera (Opera Omnia V); en 1923, Sonata de estio (Opera Omnia VI ) y Sonata de primavera (Opera Omnia V); Los cruzados de la causa y El resplandor de la hoguera en 1927 para la Biblioteca de Autores Españoles Contemporáneos de Renacimiento. Hizo también la cubierta de una de las primeras ediciones de La pipa de Kiff (cubierta azul con una ilustración de un pelícano en 1919) y había colaborado en la edición de Voces de gesta en 1912. Fue la gran revelación del tercer salón de humoristas en 1909 y desde entonces se estableció una intensa corriente de simpatía con Gómez de la Serna, que lo elogió en Tristán, "Tercer salón de humoristas", Prometeo, 11 (1909). Puede verse en Ramón Gómez de la Serna, "Palabras en la rueca", Obras completas, I. Escritos de juventud (1905-1913), pp. 273-275: "El salón de Humoristas de este ańo ha centralizado su mérito en un muchacho joven: Vivanco" (p. 273). Destacaba que concebía sus caricaturas con gran seguridad y tersura en la línea. Admirables sus fondos y su gracejo decorador. También Castelao participó en ese salón.

36 Ramón Gómez de la Serna, Obras completas, V, p. 856. 
-como si de un juego de naipes se tratara- diversas imágenes del mismo. Deja su papel al azar, a las asociaciones imaginativas plásticas y por eso lo compara a las figuras que aparecen en las puertas del Renacimiento o a Cronos: "Don Ramón procede de Cronos, así como otros proceden de Dios" 37 . Tienen mucho que ver con la figura del escritor, ya canoso y con largas barbas: "El viejo Cronos es el abuelo natural de don Ramón, que cuenta también entre sus antepasados al otro viejo Cronos de los ríos y al Cronos de las nieblas y al de los entresijos de los bosques tupidos" 38 .

Lo cual le daba pie para explorar imaginativamente otros rasgos peculiares del escritor, sus barbas y sus melenas, no solo físicamente sino como reveladoras de su personalidad y de su literatura:

Don Ramón vino al mundo con sus barbas de hilos claros, y de niño era el asombro de los demás niños con sus barbas luengas, que entonces, aunque después haya sido tan moreno, eran rubiales como las de la panocha.

Don Ramón tuvo una adolescencia fantástica, grave, de seminarista que va a ser patriarca de las Indias.

Sobre los libros cayeron sus barbas como raíces de los conceptos, como arraigo de la cabeza a las que subían las ideas por ahí.

[...] Se extasió en la selva viendo raíces como serpientes, quietas unas sobre otras en cópula inmóvil ${ }^{39}$.

Ensarta con su facilidad habitual verdaderas greguerías: "Sobre los libros cayeron sus barbas como raíces de los conceptos" ${ }^{40}$; o después va ańadiendo otras: "En los inviernos, con las ventanas cerradas y el ruido de los dedos de la lluvia que teclea sobre el zinc de las ventanas, creció la personalidad de sauce y reloj de arena que es en el fondo la de don Ramón" ${ }^{41}$. En la calle de su pueblo sonaban "las barcas de las almadreñas" ${ }^{42}$; cuando se refiera a su infancia, retomará en la biografía definitiva estas imágenes y otras, porque este retrato es la base de buena parte del de 1944: las suce-

37 Ibidem, p. 856.

38 Ibidem, p. 857.

39 Ibidem, p. 857.

40 Ibidem, p. 857.

41 Ibidem, p. 858.

42 Ibidem, p. 858. 
sivas aproximaciones le van mostrando a un don Ramón del Valle-Inclán mitad peregrino, mitad emigrante, patriarca, bohemio con melena: "paseó su melena como un rey merovingio del porvenir soviético” ${ }^{43}$.

Parte de estas comparaciones se pueden rastrear en retratos del escritor anteriores escritos por otros, otras son suyas. El retrato se va desarrollando como un juego de cartas que al descubrirlas muestran figuraciones del escritor, porque el suyo es un dictamen de echador de cartas -como ha anticipado-, un ejercicio de adivinación sucesiva:

Cada día tenía más maravillosas condiciones de faquir, y hasta conseguía fenómenos de levitación -las formas de sus ideales mujeres ascendían sobre el suelo-, y también conseguía que las semillas que aguardaban, que estaban preparadas para después, germinasen espontáneamente, y con gran antelación ${ }^{44}$.

Las imágenes de Valle-Inclán constituyen un singular tarot. Por aquí comenzamos a entender el retrato de Vivanco que ha seleccionado algunas de las imágenes: faquir, Fausto, mefisto de primera... Dedicado a esta "alquimia misteriosa" para encontrar "la palabra creadora", fue desarrollando después cada vez facultades más maravillosas convertido en "un gran adivino y mefisto de primera" ${ }^{45}$; con el tiempo es "el astrólogo de las flores, de los ecos, de los que pasan muy lejos y no se sabe si son fantasmas o son de una realidad aplastante"46; en medio de los paisajes de Galicia es "un cenobita suelto, rebelde" y "es en la tarde de ese paisaje el hombre más fantasmagórico que se conoce, el hombre que comprende la selva y que se presenta en el palacio más señorial de los contornos a pedir el predio que le pertenece..." ${ }^{27}$.

Vamos entendiendo el título del retrato y también la imagen que sugirió a Vivanco: un faquir con largas barbas sońando recostado en una llama mientras fuma su pipa, con unas sorprendentes serpientes a los pies de la llama y que se retuercen como raíces. Un personaje misterioso que evoca oriente (faquir), pero también América (la llama). Y dejándose lle-

\footnotetext{
43 Ibidem, pp. 858-861.

44 Ibidem, p. 861.

45 Ibidem, p. 861.

46 Ibidem, p. 862.

47 Ibidem, p. 863.
} 
var por esta evocación, destinada a crear una imagen fantasmagórica del escritor -misteriosa-, aún daba un paso más: “Don Ramón ha tenido la cabeza cortada" ${ }^{48}$ y de ahí su idiosincrasia, su impasibilidad, su fiera independencia; monarca degollado y repuesto, es por ello la suya

la cabeza quimérica, la cabeza resurrecta, la cabeza que no solo evoca las tallas de los muebles del Renacimiento, en que todos los adornos son barbas y guedejas del viejo y venerable genio central, sino que evoca esos colofones de los libros complicados en que los ringorrangos del pendolista o dibujante, sin que precisen una cabeza, sin precisar una fisonomía, componen un ser imaginario, un apóstol teórico, un ser formado por las rúbricas y las volutas puras, el verdadero ente del estilo ${ }^{49}$.

Ramón estaba explorando las posibilidades sugeridoras del término "fantasmagórico". El enigmático retrato de Vivanco se hace ahora transparente: Valle-Inclán es un misterioso faquir, que fuma su cachimba de marihuana mientras indaga en el sentido oculto del mundo; montado en una llama, que evoca su paso por América y en un sentido más amplio su peculiar exotismo que subraya su cachimba. Y lo que importa más, Ramón introduce algunos términos de comparación en la definición de don Ramón que pasarán a su biografía, comenzando por "fantasmagórico", lo que ya no solo lo hace misterioso, sino perseguidor de fantasmas, quimérico:

Fantasmagórico y osado, un día se fue a Extremadura con uno de los Baroja en busca de un tesoro, aunque después se complicase esa idea con otra de mayor calibre asegurando que fue un intento de dedicarse a la minería ${ }^{50}$.

O su visión del personaje como faquir -compite con su visión como un rabino que había acuñado su común amigo José Moya del Pino-, que permanecerá en la biografía de 1944, desarrollada en el capítulo X afirmando, al hablar de sus viajes a Toledo, que

48 Ibidem, p. 863.

49 Ibidem, p. 864.

50 Ramón Gómez de la Serna, Don Ramón María del Valle-Inclán, en Obras completas, XIX. Retratos y biografías, IV, p. 512. 
Don Ramón, que presumía de faquir, asombraba a todos en esos viajes. Presumía de faquir no solo porque apenas comía, sino porque fumaba has-chiss -lo escribían y pronunciaban como si estornudasen- $y$ porque tomaba las cosas ardiendo sin inmutarse.

Esa facultad faquiresca de don Ramón hizo sufrir crueles sorpresas a los que le acompańaban ${ }^{51}$.

No solamente pose o capacidad para tomar las cosas muy calientes sino resultado de una disciplina sobre la que había reflexionado en voz alta en algunas conferencias al referirse al ayuno o al has-chiss ${ }^{52}$. Es decir, esta peculiar pose era resultado de su proceso de ascesis personal y artística, de su devenir vital que lo iba haciendo cada vez más fantasmal. Fantasmal lo describe moviéndose por el pazo de La Merced durante sus ańos de agricultor. Con sus idas y venidas del campo a la ciudad, "Valle resultaba un ser misterioso y torturado por la disputa del campo y la ciudad" 53 . Iba de un lado a otro, "era el pasajero y venía de lejos para ir más lejos", lo que le llevaba a preguntarse a Ramón en su biografía:

¿Fue el peregrino que quiso unir La Meca, el centro de las peregrinaciones islámicas, con Santiago de Compostela, el centro de las peregrinaciones cristianas? ?4 $^{5}$

Todo le venía bien a Ramón para dotar de una personalidad misteriosa al escritor gallego, que amplía con otras anécdotas e ideas en el capítulo XII hasta ir a parar a su retrato del personaje envejecido, "mensajero melenudo y estrafalario", pero siempre misterioso, un verdadero santón que pinta fantásticamente:

Así como a los faquires les llega un momento en que parecen muertos y se les lleva a un lugar especial y custodiado donde se les conserva en ese estado cataléptico hasta que por medio de masajes y otros ritos se les devuelve a la vida, así Valle-Inclán estaba incorrupto en su casa y

51 Ibidem, p. 552.

52 Ibidem, p. 558.

53 Ibidem, p. 578.

54 Ibidem, p. 580. 
salía a ver comer naranjas frías a los niños congelados.

Valle-Inclán había llegado a los éxtasis de la panoplia y se entraba y se salía por los cajones de su bargueño.

Estaba en la hora del faquirismo auténtico, tapados los oídos, la nariz y cortado el frenillo de la lengua como hacen los auténticos faquires para taponarse al exterior, aprovechando su hambre proverbial para que su estado místico llegase a la supremidad 55 .

Es en ese punto y momento en el que la identificación con él se hace mayor porque le lleva a la consideración del escritor en España:

No le avergonzaba su pobreza por todo eso y porque así nos enseñaba lo más digno que se puede enseñar, que es a conllevar la pobreza.

Yo, que me he sentido malhumillado y avergonzado junto a tantos hombres, a la vera de Valle-Inclán me sentía orgulloso, feliz, en compañía de una primerísima dignidad.

Sobre su personalidad había como una autoridad delegada de lo alto, como la que cayó sobre los apóstoles cuando los muy rústicos comenzaron a hablar todas las lenguas y a decir secretos de Dios.

[...] Esa cosa jesucrestal que yo veía en Valle me le hacía más respetable, más amable y nunca pisé su sombra. ¿Es de ciegos creer más ungido al sacerdote que al santo peregrino?

El que no se toma tiempo para ver llegar lo que a lo mejor no llega nunca, no es artista cabal.

El que trapichea mucho busca cargos de influencia para halagar a los vulgares y entrometidos hambrones, es inútil que quiera ser el literato que vivió la delicia inefable, aunque haya muerto en la indigencia.

Valle conservó ese señorío en la espera, en ese vivir en acecho de cazador furtivo para no traer un mal conejo que echar al puchero porque él esperaba cazar dentro de varios años la posible pieza unicórnica $^{56}$.

El tono elegíaco es indudable en pasajes como este. Y la fraternidad de quien se siente también escritor y ninguneado socialmente. Pero él no se doblegaba, no cedía. Cómo él mismo, que se siente ya escritor heroico y

55 Ibidem, p. 581.

56 Ibidem, p. 582. 
por ello no tiene pudor en discurrir sobre sus disparates a la vez que sobre el esperpento a lo largo del capítulo XIV, fórmulas las dos apropiadas para expresar la desazonante condición de la vida española. Y como los peripatéticos personajes de Luces de bohemia, atraviesa la noche madrileña sin dejar de seguir explorando la imagen del faquir:

En mis encuentros en la noche, cuando iba o venía solo, se me presentó amargado de esa aceptación, de aquel borbotoneo confesionario en que gritaban los sarasas siguiéndole jocundos y cascabeleros ${ }^{57}$.

O después entrelazando su visión de don Ramón con su particular barba y como faquir:

En alguna noche de aquellas de cierzo y agua en que volvíamos del café sin paraguas, su aspecto de pájaro augural era terrible, con la barba pegada a la sotabarba, con algo de pájaro ahogado.

Barba de faquir sobre todo, ya que él, que confesaba que su alma era la de un antiguo faquir que podía milagrear y resistir todos los dolores, cuando fumaba su larga pipa de Kiff, se le veía lo natural que era del Oriente ${ }^{58}$.

Habituado a tomar y retomar sus hallazgos y expresiones, no dudaba en reiterar un poco después lo que hacía algunos años había publicado como greguería en $L u z$ :

La barba de Valle-Inclán ya era cosa de humo, un humo que iba hacia abajo como esos cendales de los grandes puertos pirenaicos que barban los abismos ${ }^{59}$.

Ramón Gómez de la Serna cogía una palabra o una frase como quien coge una esponja empapada de agua y empezaba a apretarlas caprichosamente, para que fueran soltándola: es una de las maneras de crear sus greguerías. Pongamos un ejemplo. Coge las barbas de don Ramón y empieza a estrujarlas. Las barbas se convierten en greguería estricta en 1924, cuando

57 Ibidem, p. 598.

58 Ibidem, p. 624.

59 Ibidem, p. 625. 
dentro de la serie que contienen “Tribuna libre: greguerías”, publicada en Luz el 17 de marzo había incluido esta: "Las barbas de Valle-Inclán son de humo, un humo hacia abajo en vez de ser un humo hacia arriba." Después la retoma en su biografía como una variación.

No faltan nunca las barbas de don Ramón en los escritos ramonianos. La escritura ramoniana recicla lo anterior, pero siempre creativamente, brotando nuevas ramas. Están ya las barbas muy presentes en el retrato que incluye de don Ramón en Azorín, luego amplía según la ocasión. No deja de advertirlo:

Dos siluetas he hecho de Valle-Inclán y no voy a repetir aquí nada de lo dicho en ellas; queda la más fantasmagórica en mi libro El alba y la otra en un capítulo de Muestrario, donde cuento las mil y una maneras de cómo perdió el brazo don Ramón.

Las palabras dedicadas a Valle-Inclán merecen pesarse en balanza de platero, porque es el más difícil tipo de artista español que se conoce $^{60}$.

Cumple solo en parte su afirmación de que no va a repetirse, porque acaban reapareciendo imágenes ya acuñadas junto a otras nuevas. Hacia el final, por ejemplo, retoma la imagen del escritor como "Viejo Cronos que asiste al juicio oral de las noches, espanta a los merodeadores de la viña del $\operatorname{arte}^{\text {"61 }}$; también su carácter fantasmal:

A Valle-Inclán le tienen gran respeto estos jóvenes que le ven llegar con luengas barbas y luengas guedejas del fondo hiperbóreo de las apariciones celtas, medio señorito hidalgo, medio uno de esos espectros envuelto en una sábana que se presentan con tipo de Valle-Inclán a los médiums fotográficos ${ }^{62}$.

El retrato incluido en Azorín es quizás peor que los anteriores, en buena parte un ensartado de anécdotas. Pero otras son verdaderos hallazgos: "Valle es un hipertiroideo del arte y está quemado y enjutado en fuego de

60 Ramón Gómez de la Serna, Azorín, en Obras completas, XIX. Retratos y biografias, p. 115.

61 Ibidem, p. 120.

62 Ibidem, p. 115. 
su tiroides, en carburación de su alma"63. O la exploración greguerística -una vez más- de sus barbas:

Siempre han sido barbas orgullosas, de las que él podría decir lo que el Cid Campeador dijo llevándose la mano a las suyas durante su altercado con Garci Ordóñez.

En esta última época, las barbas de don Ramón se han adelgazado, y se han atenuado, convirtiose en un cendal de esos que flotan en las cumbres al amanecer.

A través de estas últimas barbas de Valle-Inclán se transparece su garganta, de poderosa nuez, y se deja ver que no lleva la golilla supuesta, quedando en cierta desnudez la gárgola de su elocuencia.

De tanto deshilarlas con el cardar constante de su única mano, en un gesto de eterno lencero de la palabra, parece que ha ido sembrando de hebras el tiempo... ${ }^{64}$

Y el recuerdo del escritor visto atentamente desde los años de su infancia comienza a tener papel relevante:

A Valle-Inclán en mi infancia le veía por la biblioteca del antiguo Círculo de Bellas Artes, asomándose a ella después de la charla en los salones del tresillo con los artistas en época de delirio. Allí repasaba las Ilustraciones, con predilección la italiana ${ }^{65}$.

Están muy presentes sus barbas también en "D. Ramón del Valle-Inclán”, incluido en Retratos contemporáneos y alcanzarán toda su relevancia en alguno de sus artículos posteriores: «Misterio de Valle-Inclán. Nuevas palabras sobre su estética y sobre su barba», publicado en La Nación de Buenos Aires el 25 de abril de1943.

La dinámica del trabajo de Ramón no la marcan los datos biográficos del personaje -que están reducidos al mínimo y era asunto que quedaba fuera de sus intereses- sino las imágenes que se fue haciendo de él a través de su trato, a través de sus lecturas que incorporará con breves apuntaciones críticas en su biografía, a través de las imágenes que ha visto suyas,

63 Ibidem, p. 115.

64 Ibidem, p. 119.

65 Ibidem, p. 115. 
pero sobre todo con ese planteamiento adivinatorio que marca la pauta de su retrato en La Pluma y que continúa cuando vuelve a escribir en 1924 otro retrato de don Ramón con el mismo modelo de escritura. El escritor había estado internado en un sanatorio de Santiago, después volvió a Madrid. Ramón en Nuevo Mundo le dedica otro retrato genial que no he visto nunca analizado ni apenas citado: "El escritor en la enfermería" (18-VII-1924) [Figs. 7 y 8]. Son otra serie de sucesivas aproximaciones basadas en imágenes para retratar al "viejo cabecilla":

\section{EL ESCRITOR EN LA ENFERMERIA}

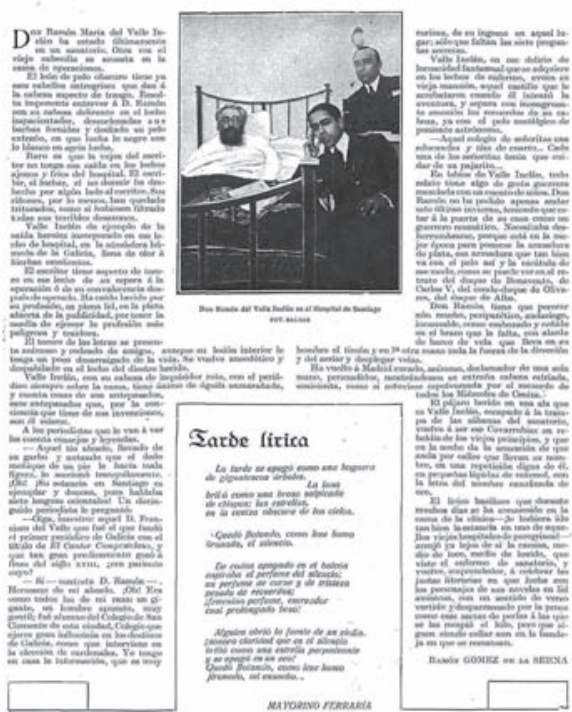

Fig. 7. Ramón Gómez de la Serna, "El escritor en la enfermería", Nuevo Mundo, 18/VII/1924.

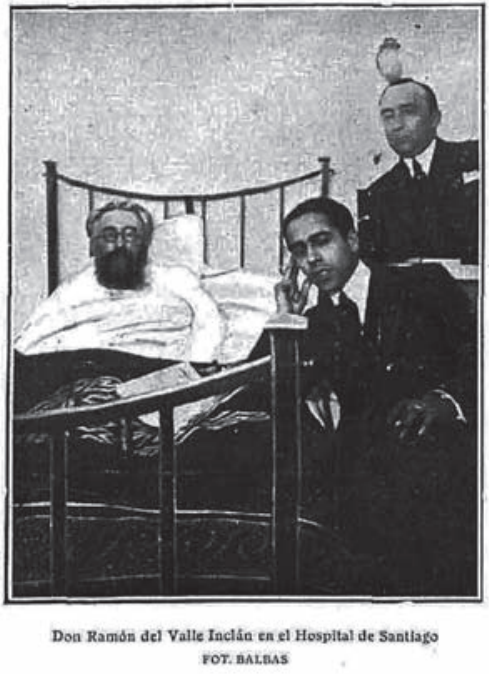

Fig. 8. Ramón Gómez de la Serna, "El escritor en la enfermería", Nuevo Mundo, 18/VII/1924 (detalle).

El león de pelo obscuro tiene ya esos cabellos entregrises, que dan a la cabeza aspecto de trasgo. Resulta imponente entrever a D. Ramón con su cabeza delirante en el lecho impacientador, desmelenadas sus barbas fornidas y desliado su pelo extraño, en que lucha lo negro con lo blanco en agria lucha.

Raro es que la vejez del escritor no tenga esa caída en los lechos ajenos y fríos del hospital. El escribir, el luchar, el no dormir ha deshe- 
cho por algún lado al escritor. Sus riñones por lo menos, han quedado triturados como si hubiesen filtrado todas sus terribles desazones.

Valle-Inclán da ejemplo de la caída heroica incorporado en ese lecho de hospital, en la atmósfera húmeda de Galicia, llena de olor a hierbas emolientes.

El escritor tiene aspecto de torero en ese lecho de su espera a la operación o de su convalecencia después de operado. Ha caído herido por su profesión, en plena lid, en la plaza abierta de la publicidad, por tener la osadía de ejercer la profesión más peligrosa y osada.

El torero de las letras se presenta animoso y rodeado de amigos, aunque su lesión interior le tenga un poco desarraigado de la vida. Se vuelve anecdótico y despabilado en el lecho el diestro herido.

Valle-Inclán, con su cabeza de inquisidor roto, con el periódico siempre encima de la cama, tiene ánimo de águila enmarañada, y cuenta cosas de sus antepasados, esos antepasados que, por la conciencia que tiene de sus invenciones, son él mismo ${ }^{66}$.

Curtido en mil batallas de la vida literaria y conocedor de sus miserias, andaba Ramón en aquellos años muy ocupado indagando en las implicaciones de la palabra escritor. Y para el retrato de Valle-Inclán ahora se apropia del lenguaje taurino para trasladarlo a la pintura del escritor, presentado como varón doliente en su lecho, es decir, al margen de la gloria del triunfo de la plaza: en la enfermería, corneado por el toro de la enfermedad, causada por una vida artística de lucha tenaz en el ruedo ibérico.

Para Ramón, Valle-Inclán representa ya el arquetipo del escritor espańol heroico que ha apostado toda su vida por la literatura. Paga el precio de su lucha: es un "león de pelo obscuro" con "cabellos entregrises, que dan a la cabeza aspecto de trasgo". ¿Latía la vieja personificación del heroísmo en el león español que tanto habían utilizado publicaciones progresistas como la revista Don Quijote en el cambio de siglo? Y retoma otra imagen que connota la misma nobleza: "Con su cabeza de inquisidor roto [...] tiene ánimo de águila enmarañada”. León y águila, pero heridos. No renuncia a seguir fabulando y "en ese delirio de locuacidad fantasmal" transforma cuanto cuenta en literatura:

66 Ramón Gómez de la Serna, "El escritor en la enfermería", Nuevo Mundo, 18-71924. La idea permanece en la biografía cuando cuenta cómo fantaseaba sobre sus orígenes. 
En labios de Valle-Inclán, todo relato tiene algo de gesta guerrera mezclada con un cuento de niños. Don Ramón, no ha podido apenas andar este último invierno, teniendo que estar a la puerta de su casa como un guerrero reumático. Necesitaba desherrumbrarse, porque está en la mejor época para ponerse la armadura de plata, esa armadura que tan bien va con el pelo así y la carátula de ese modo, como puede verse en el retrato del duque de Benavente, de Carlos V, del Conde-duque de Olivares, del duque de Alba.

Don Ramón tiene que perorar aún mucho, peripatético, andariego, incansable, como embozado y ceñido en el brazo que le falta, con alarde de barco de vela que lleva en su hombro el timón y en la otra mano toda al fuerza de la dirección y del arriar y desplegar velas.

Ha vuelto a Madrid curado, animoso, declamador de una sola mano, persuadidor, mostrándonos su extrańa cabeza estriada, cenicienta, como si estuviese espolvoreada por el recuerdo de todos los Miércoles de Ceniza.

El pájaro herido en una ala que es Valle-Inclán, escapado a la trampa de las sábanas del sanatorio, vuelve a ser ese Covarrubias en rebeldía de los viejos principios, y que en la noche da la sensación de que anda por calles que llevan su nombre, en una repetición digna de él, en pequeñas lápidas de mármol, con la letra del nombre canalizada de oro.

El lírico basilisco que durante muchos años se ha consumido en la cama de la clínica - ¡le hubiera ido tan bien la estancia en uno de aquellos viejos hospitales peregrinos!- arrojó ya lejos de sí la camisa, medio de loco, medio de herido, que viste el enfermo de sanatorio, y vuelve emprendedor, a celebrar las fiestas literarias en que lucha con los personajes de sus novelas en lid amistosa, con un sentido de verso vertido y desparramado por la prosa como esas sartas de perlas a las que se las rompió el hilo, pero que siguen siendo un collar aún en la bandeja en que se remansan ${ }^{67}$.

El brazo cortado de don Ramón sigue dando lugar a brillantes imágenes -otro diría greguerías- que sorprenden: "barco de vela que lleva en su hombro el timón”, "pájaro herido en una ala”, "lírico basilisco"... De estos flecos brillantes y luminosos de la nube en expansión que fueron los 
escritos de Ramón sobre don Ramón solo parte ha pasado a su biografía de 1944. En su capítulo XVI, transcribe prácticamente todo el largo fragmento que acabo de citar, pero realiza desarrollos como con casos anteriores $^{68}$. Su final está bien evocarlo y jugarlo aquí para que rebrille de nuevo, tan lleno de ecos de la poesía arabigoandaluza, cuando ve su escritura "con un sentido de verso vertido y desparramado por la prosa como esas sartas de perlas a las que se las rompió el hilo, pero que siguen siendo un collar aun en la bandeja en que se remansan."

Creo que, aun sin un careo exhaustivo, habrá ido quedando claro el proceder de Ramón en sus escritos valleinclanianos, ideando imágenes que después retoma y amplía. El "Prólogo" de su biografía en 1944 es bastante clarificador; remitiendo a sus escritos anteriores, a su semblanza incluida en Retratos contemporáneos, dice: "pinté un cuadro bastante completo del escritor, retrato del que algunos han tomado la manera y la anécdota sin poner en la tablilla la palabra copia, ya que lo que hicieron el retrato de un retrato y no el retrato de la fisonomía natural por su cuenta y riesgo" ${ }^{69}$. Decía ahora haber sido señalado por el escritor como su biógrafo porque había leído muchas de sus biografías y en particular la de Azorín (1930) donde perfiló la época y le dedicó un capítulo entero que le gustó. Mal lo podía desmentir y previsiblemente hubiera visto con agrado esta biografía donde retomaba materiales y donde su afán era "mostrarle y mostrarme a su lado, ultimando esa prueba terminante que es la corroboración, hecha por el que sigue viviendo, del que fue su contemporáneo y su amigo que ya murió" 70 .

Gómez de la Serna insistía en que "en una biografía es importante la entonación y la moralidad del biógrafo, que ha de ser un literato suficientemente puro y que, además, no alargue lo que no debe alargar, hasta hacer mentiroso lo verdadero" 71 .

No le cabía ya la menor duda de que don Ramón era el escritor ejemplar, "un ejemplo excelso como prototipo de escritor digno, dedicado, como quien no hace la cosa, a la captación de la palabra de arte que ha de complacer siempre a la Humanidad, y que será lo único que no

68 Ramón Gómez de la Serna, OC, XIX. Retratos y biografías, IV, pp. 604-605.

69 Ibidem, p. 465.

70 Ibidem, p. 467.

71 Ibidem, p. 465. 
será riqueza echada en saco roto"72. Quería que alentara a través de toda la biografía su lado "misterioso y legendario", "emisario de lo ignoto" a quien "lo mismo se le podía llamar demiurgo que taumaturgo", "un tipo inverosímil que adornó la vida como una viñeta temeraria y delirante"73; "un ser misterioso que trajo un mensaje del más allá a la vida y se lo llevó sin quererlo acabar de leer"74.

\section{PARA CONCLUir}

Podríamos decir que Gómez de la Serna con Valle-Inclán procedió como un pintor: comenzó por apuntes del personaje, trazando su silueta, después fue abocetando el retrato, desarrollando rasgos con pinceladas más numerosas y matizadas y finalmente atacó el retrato que resultó definitivo en su biografía en 1944, superponiendo en sucesivas veladuras los tanteos anteriores. $\mathrm{O}$ si se prefiere, podemos tomar su expresión de "Las palabras en la rueca": el escritor que hila y devana las palabras y con ellas teje sus escritos. Ramón teje una y otra vez su retrato literario de Valle-Inclán. Corta la tela y cose el traje a su desmedida medida, como decía al principio, sin prestar mucha atención a los patrones establecidos.

Es importante recalcar, concluyendo, que esta biografía ocupó un lugar notable durante bastantes años en los estudios sobre don Ramón, solo contrapesada por la tendenciosa e incompleta que publicó por las mismas fechas Melchor Fernández Almagro, soslayando los episodios conflictivos como requerían los cánones del primer franquismo. Y por esto acaso es por lo que durante mucho tiempo perduró una visión pintoresca y anecdótica de aquel gran escritor peripatético, la mejor máscara a pie que cruzaba la calle de Alcalá. No se entendió muchas veces, que había que trascender las anécdotas y ahondar tratando de comprender su sentido. De aquí la omnipresencia en nuestros propios relatos de las anécdotas relacionadas con la pérdida de la mano. Es cierto que es sustancial para comprender a Valle-Inclán la multitud de retratos plásticos y literarios que fue dejando tras de sí, que hoy por fortuna van siendo sometidos a

72 Ibidem, p. 466.

73 Ibidem, p. 466.

74 Ibidem, p. 468. 
procesos de recuperación y análisis cada vez más sistemáticos ${ }^{75}$. También en esto fue pionero Ramón insertando en su biografía fragmentos de retratos que habían hecho otros: Pedro de Répide, Maeztu, Juan Ramón Jiménez, etc. Es un peligro quedarse en lo anecdótico como bien lo advirtió José Bergamín. A Ramón también le preocupaba que no se advirtiera que las anécdotas no eran sino la capa más superficial de su retrato, un emplasto para proteger su desvalida humanidad.

Terminado este ensayo, ordenando parte del archivo de Daniel Devoto y María Beatriz del Valle-Inclán, llega a mis manos una preciosa carta de Ramón, que resume bien cómo escribió su biografía de don Ramón en Buenos Aires, teniendo delante de él retratos del biografiado que nutrieron su "sonambúlica obra de admiración y justicierismo"; dirigida la carta a Mariquiña del Valle-Inclán que, al parecer, le había proporcionado alguna información, sirve a la perfección como síntesis de lo expuesto en nuestro ensayo:

RAMON GOMEZ DE LA SERNA

BUENOS AIRES

VICTORIA I 970

TEL. $47 \cdot 4775$

Mi querida Mariquiña:

Muchas gracias por sus referencias a esos versos admirables de su padre, nuestro gran Don Ramón.

Está bien que consulte con Jaime por si pudieran completarse, pues tienen la inmensa amargura que merecía la España literaria que no se portó como debía con él y logró que se fuera más pronto de lo que debía haberse marchado.

Estoy frente a un caballete lleno de retratos de él, procreando mi sonambúlica obra de admiración y justicierismo.

Con muchos recuerdos a su esposo es su muy devoto

\section{RAMÓN}

75 Jesús Rubio Jiménez, Valle-Inclán caricaturista moderno. Javier Serrano Alonso y Amparo de Juan Bolufer, Valle-Inclán dibujado ldibuxado. Caricaturas y retratos del escritor /caricaturas e retratos do escritor (1888-1936), Concello de Lugo, 2008. Véase asimismo VV.AA., Retratos de Valle-Inclán, Pontevedra, Museo de Pontevedra, 2012. 
Muchos recuerdos de Luisita.

El recorte que le envío está un poco mal recortado pero se puede leer $^{76}$.

76 Pertenece al Fondo Daniel Devoto-María Beatriz del Valle-Inclán, depositado en la Fundación Lázaro Galdiano (Madrid). 